\title{
Occurrence of a single-species cyanobacterial bloom in a lake in Cyprus: monitoring and treatment with hydrogen peroxide-releasing granules
}

\author{
Eleni Keliri ${ }^{1}$, Christia Paraskeva ${ }^{1}$, Angelos Sofokleous ${ }^{1}$, Assaf Sukenik² ${ }^{2}$ Dariusz Dziga ${ }^{3}$, Ekaterina Chernova ${ }^{4}$,
} Luc Brient ${ }^{5}$ and Maria G. Antoniou ${ }^{1 *}$ (D)

\begin{abstract}
Background: Excess loads of nutrients finding their way into waterbodies can cause rapid and excessive growth of phytoplankton species and lead to the formation of cyanobacterial harmful algal blooms (cyano-HABs). Toxic cyanobacteria produce a broad range of bioactive metabolites, some of which are known as cyanotoxins. These metabolites can negatively impact the ecosystem, and human and animal health, thus their presence needs to be closely monitored and mitigated. This study aimed to monitor St. George Lake (Athalassa National Forest Park, Cyprus) for its water quality characteristics, and initiate a new methodology to control the bloom that occurred in the lake during summer 2019, by comparing hydrogen peroxide treatment with novel metallic peroxide granules as source of hydrogen peroxide.
\end{abstract}

Results: Lake monitoring showed that $\mathrm{pH}$, salinity, total dissolved solids and conductivity varied throughout the year, and nutrients concentration was high, indicating a eutrophic lake. The cyanobacterium Merismopedia sp. bloomed in the lake between June and September 2019, comprising up to 99\% of the phytoplankton biovolume. The presence of microcystin synthase encoding gene ( $m c y B$, mcyE) was documented, however microcystins were not detected by tandem mass spectroscopy. Treatment with liquid hydrogen peroxide in concentrations 1 to $5 \mathrm{mg} \mathrm{L}^{-1}$ had no effect on the phycocyanin fluorescence (Ft) and quantum yield of PSII (Fv/Fm) indicating an ineffective treatment for the dense Merismopedia bloom (1 million cells $\mathrm{mL}^{-1} \pm 20 \%$ ). Metallic peroxide granules tested for their $\mathrm{H}_{2} \mathrm{O}_{2}$ releasing capacity in St. George Lake water, showing that $\mathrm{CaO}_{2}$ released higher $\mathrm{H}_{2} \mathrm{O}_{2}$ concentration and therefore have better mitigation efficiency than $\mathrm{MgO}_{2}$ granules.

Conclusion: The present study highlights the importance of monitoring several water parameters to conclude on the different actions to be taken to limit eutrophication in the catchment area. The findings demonstrated that testing for the presence of genes involved in cyanotoxin production may not be sufficient to follow cyanotoxins in the water, therefore it should be accompanied with analytical confirmation. Treatment experiments indicated that slow release of $\mathrm{H}_{2} \mathrm{O}_{2}$ from peroxide granules may be an alternative to liquid hydrogen peroxide when applied in appropriate doses, but further investigation is needed before it is applied at the field.

\footnotetext{
*Correspondence: maria.antoniou@cut.ac.cy

${ }^{1}$ Department of Chemical Engineering, Cyprus University of Technology,

3036 Lemesos, Cyprus

Full list of author information is available at the end of the article
} adaptation, distribution and reproduction in any medium or format, as long as you give appropriate credit to the original author(s) and the source, provide a link to the Creative Commons licence, and indicate if changes were made. The images or other third party material in this article are included in the article's Creative Commons licence, unless indicated otherwise in a credit line to the material. If material is not included in the article's Creative Commons licence and your intended use is not permitted by statutory regulation or exceeds the permitted use, you will need to obtain permission directly from the copyright holder. To view a copy of this licence, visit http://creativeco mmons.org/licenses/by/4.0/. 
Keywords: Cyanobacteria, Granules, Hydrogen peroxide, Merismopedia sp., Monitoring, Nutrients, Treatment, Water quality

\section{Background}

Cyanobacteria are phytoplankton microorganisms whose ability to oxygenate the atmosphere 3.5 billion years ago contributed to life formation [1]. It is a group of bacteria ranging from 1 to $100 \mu \mathrm{m}$ in diameter, while some of them are even smaller having a diameter less than $1 \mu \mathrm{m}$. Those are described as picoplankton and include species such as Merismopedia, Aphanocapsa, and Synechococcus sp. [2]. These species belong to the order of Synechococcales and can be described as spherical or oval cells with the tendency to form flat mats or sheets by being arranged in rows. In general, cyanobacteria gain energy from photosynthesis by capturing light through pigments. There is an array of photosynthetic pigments present in cyanobacterial species, predominated by phycocyanin which has a distinctive excitation wavelength at $\lambda=620 \mathrm{~nm}$ that distinguishes them from green-algae and other phytoplankton taxa [3].

Anthropogenic activities such as agricultural, urban, and industrial activities have intensively increased the load of nutrients in surface waters around the globe, making cyanobacterial blooming more persistent and prevalent [4]. Along with other factors such as light, temperature, phytoplankton and zooplankton; both nutrients and cyanobacteria are essential components in the aquatic ecosystem to maintain its balance [5]. Disruption of this balance by excess load of nutrients causes their rapid and excessive growth which leads to the formation of cyanobacterial harmful algal blooms (cyano$\mathrm{HABs}$ ). Blooms decline water quality by reducing light and causing oxygen depletion with serious consequences on aquatic biodiversity [6], while adding undesirable color, taste, and odor to water. Toxic cyanobacteria can release into the water a broad variety of bioactive metabolites, some of them known as cyanotoxins [7]. These metabolites can negatively impact the ecosystem and human health, making it an important environmental issue of concern [8]. Although their acute toxicity on humans is not extensively studied, mass mortalities of fishes, birds, mammals, and many other animal taxa have been reported [9]. Recent studies have correlated liver-related deaths in the US with several cyanotoxins [10]. Cyano-HABs presence in freshwaters used as drinking water reservoirs is not only a health issue, but it also raises the overall treatment and monitoring costs which are in the range of millions of euros annually [11]. Currently, there is no method for in situ detection or a predictive model for the occurrence of these toxins since not all cyanobacterial species are active toxin producers under the same conditions. Therefore, it is imperative to find both monitoring tools and efficient treatment methods to mitigate the problem to safeguard water quality and reduce water treatment costs at source and in the waterworks.

The concentration (total and dissolved fraction) of the main nutrients-nitrogen (TN) and phosphorus (TP), is a strong indicator of the eutrophic state of waterbodies thus, several models have been developed over the years to form correlations [12]. Monitoring of nutrients in waterbodies and estimating their corresponding ratios is critical for improving the applied management strategies to better control the limiting factors of a bloom, and to prevent future blooming events. Surface water monitoring is not only essential for maintaining a healthy status but also to protect the biodiversity of aquatic biotopes around EU. Unfortunate events of high nutrient loads that lead to the formation of cyano-HABs are mostly unpredictable, thus highly efficient methods are required to be applied in situ for lake restoration.

There are several physical, chemical, and biological treatment methods that have been developed and applied over the years with the chemical ones to be more cost effective, rapid, and efficient [13]. A recent study has summarized the new insights on green photocatalytic oxidation for cyanotoxins and cyanobacteria from pure cultures and field samples [14]. The need to make chemical treatment "greener" has led to the application of hydrogen peroxide $\left(\mathrm{H}_{2} \mathrm{O}_{2}\right)$ as an alternative to copper algicides, resulting in selective reduction of cyanobacterial species among other taxa of phytoplankton $[15,16]$. The hydroxyl radicals $(\mathrm{OH})$ formed by the oxidant inhibit the electron transport of photosystem II (PSII), causing reduction of its photosynthetic activity and leading to cellular death $[17,18]$. The efficiency of such treatment varies and depends on the nutrient load of the matrix, the species composition and abundance, the bloom density, and light intensity. Usually doses of $\mathrm{H}_{2} \mathrm{O}_{2}$ over $5 \mathrm{mg} \mathrm{L}^{-1}$ are required for the complete destruction of cyanobacterial cells [19], which are considered high for the freshwater environment and potentially toxic to the remaining ecosystem [20]. An alternative to liquid hydrogen peroxide is its granular form found as metallic peroxide granules $\left(\mathrm{CaO}_{2}\right.$ and $\left.\mathrm{MgO}_{2}\right)$ which decompose slowly and release $\mathrm{H}_{2} \mathrm{O}_{2}$ as shown in Eqs. 1 and 2 [21]:

$$
\mathrm{CaO}_{2}+\mathrm{H}_{2} \mathrm{O} \rightarrow \mathrm{Ca}(\mathrm{OH})_{2}+\mathrm{H}_{2} \mathrm{O}_{2}
$$




$$
\mathrm{MgO}_{2}+\mathrm{H}_{2} \mathrm{O} \rightarrow \mathrm{Mg}(\mathrm{OH})_{2}+\mathrm{H}_{2} \mathrm{O}_{2}
$$

The first aim of the current study was to monitor the status of St. George Lake to correlate its trophic condition with water quality characteristics and to identify the key environmental variables driving cyanobacterial blooming. Another aim was to examine the treatment efficiency of metallic peroxide granules on a dense singlespecies natural bloom that occurred in St. George Lake. We hypothesized that peroxide granules would have the ability to destroy cyanobacterial cells by inhibiting the PSII electron transfer in the same way as $\mathrm{H}_{2} \mathrm{O}_{2}$ does, but in a more gradual and controlled manner, simulating multiple additions of liquid hydrogen peroxide. To do that, we first determined the kinetics of the $\mathrm{H}_{2} \mathrm{O}_{2}$ release by $\mathrm{CaO}_{2}$ and $\mathrm{MgO}_{2}$ granules into the St. George water matrix. Then we compared the efficiency of the two peroxide granules in reducing the maximal efficiency yield of PSII (QY) during a 48-h treatment while monitoring pigments' fluorescence signal and residual oxidant concentration. Since, the bloom was recorded during the summer months of the monitoring period, it was essential to determine the most appropriate dose for its successful mitigation as Merismopedia sp., the dominant specie of the bloom, has been reported in the literature as a potential toxin producer. This study aimed to address all of the above in order to propose an efficient treatment method for in-lake application to restore water quality.

\section{Materials and methods Study area}

Saint George Lake is located at the Athalassa National Forest Park (ANFP) in Nicosia, the capital city of Cyprus. It is an artificial lake which covers an area of $68,000 \mathrm{~m}^{3}$ with an average depth of approximately $2 \mathrm{~m}$. ANFP covers an area of $8.5 \mathrm{~km}^{2}$ and it is found between Aglantzia, Strovolos, Latsia, and Geri municipalities; four of the most densely populated locations in Nicosia. Athalassa Lake and Saint-Gorge Lake (Additional file 1: Scheme S1) serve as aquatic life and bird habitats, making them an extremely important biotope for the island. The present study focuses on monthly monitoring of the St. George Lake for a 1-year period, in terms of nutrient concentration, cyanobacterial content, and toxicity.

\section{Sampling and monitoring}

Sampling was performed at a central part of the lake and water was collected from a depth of 0.1-0.2 $\mathrm{m}$ below the surface. Three water samples were collected each time and stored in acid-washed polyethylene (PE) bottles for the physicochemical water characterization and treatment purposes, and in glass containers for cyanobacterial genes and cyanotoxins analyses. All samples were stored at $4-6{ }^{\circ} \mathrm{C}$ in the dark, brought to the laboratory, and processed within $6 \mathrm{~h}$ after sampling to ensure high accuracy and prevent decomposition of the water characteristics.

The monitoring of St. George Lake occurred between February and December 2019, and 10 samples were collected overall during the year (Additional file 1: Table S3). The main physicochemical parameters $(\mathrm{pH}$, conductivity, salinity, total and dissolved nutrients), the presence of cyanobacteria and green algae in terms of fluorescence signal (Fv), maximum yield of PSII (QY), and microscopic observation, the content of genes for main cyanotoxins synthesis, and the concentration of cyanotoxins were determined. Samples were also collected during the blooming period (August 2019) for treatment experiments with liquid hydrogen peroxide and hydrogen peroxide-releasing granules.

\section{Physicochemical water characteristics analyses}

Raw samples were analyzed for total nitrogen (TN) and total phosphorus (TP) while samples filtered through cellulose nitrate membrane filter $(0.45 \mu \mathrm{m})$ were analyzed for the dissolved nutrients content (ammonium- $\mathrm{NH}_{4}{ }^{+}$, nitrates $-\mathrm{NO}_{3}{ }^{-}$, nitrites $-\mathrm{NO}_{2}{ }^{-}$, and phosphates$\left.\mathrm{PO}_{4}{ }^{3-}\right)$. Nutrients were determined by using Spectroquant ${ }^{\circledR}$ cell test kits (Merck Millipore) equivalent to EPA and APHA standard analytical methods and the Spectroquant ${ }^{\circledR}$ Pharo 300 spectrophotometer (Merck) with method standard deviations $\pm 0.15 \mathrm{mg} \mathrm{L}^{-1}-\mathrm{N}, 0.027$ $\mathrm{mg} \mathrm{L}^{-1} \mathrm{PO}_{4}-\mathrm{P}, 0.043 \mathrm{mg} \mathrm{L}^{-1} \mathrm{NH}_{4}-\mathrm{N}, 0.13 \mathrm{mg} \mathrm{L}^{-1} \mathrm{NO}_{3}-\mathrm{N}$, $0.0027 \mathrm{mg} \mathrm{L}^{-1} \mathrm{NO}_{2}-\mathrm{N}$, respectively. Dissolved inorganic nitrogen was calculated as the sum of dissolved nitrogen ions $\left(\mathrm{NH}_{4}{ }^{+}, \mathrm{NO}_{3}{ }^{-}, \mathrm{NO}_{2}{ }^{-}\right)$. Temperature, $\mathrm{pH}$, conductivity, and salinity were measured at the sampling site using the ExStik ${ }^{\circledR}$ portable pH meter (EXTECH, FLIR Systems).

\section{Phytoplankton content}

Instantaneous fluorescence $(\mathrm{Ft})$ and quantum yield $(\mathrm{QY})$ of the PSII were determined using AquaPen AP 110/C (Photon Systems Instruments, Czech Republic) equipped with blue and red LED light emitters. Blue excitation wavelength at $450 \mathrm{~nm}$ represents the instantaneous chlorophyll-a fluorescence and red excitation wavelength at $620 \mathrm{~nm}$ represents the phycocyanin fluorescence, both in raw fluorescence units (RFU). The maximum quantum yield of the PSII was recorded on both wavelengths as a fraction of the maximal variable fluorescence $\left(\mathrm{F}_{\mathrm{v}}\right)$ to the maximal fluorescence intensity in the dark-adapted (5-min adaptation) state $\left(\mathrm{F}_{\mathrm{m}}\right)$. The instrument was used to monitor the growth of algae and cyanobacteria in St. George Lake.

For the characterization of cyanobacterial species in water samples, raw sample was placed directly or after filtration (cellulose nitrate filter, $0.45 \mu \mathrm{m}$ ) on a microscopy 
slide and tested under ECLIPSE Ci-L microscope (Nikon) equipped with OPTIKAM Wi-Fi camera (OPTIKA $^{\circledR}$, Italy). Phytoplankton samples were preserved with Lugol's iodine solution ( $2 \%$ final concentration), stored in $4-6{ }^{\circ} \mathrm{C}$ under dark conditions and used within 3 weeks.

\section{DNA isolation and PCR amplification}

DNA isolation from the biomass collected on cellulose nitrate filters was performed as described by Rogers and Bendich (1994) with minor modifications [22]. Briefly, filters were placed in 2-mL Eppendorf tubes, frozen in liquid nitrogen and grinded. Glass beads $(150-212 \mu \mathrm{m})$ were added in ratio 1:1 and the content was dissolved in $700 \mu \mathrm{L}$ of the extraction buffer I $(100 \mathrm{mM}$ Tris, $1.3 \mathrm{M}$ $\mathrm{NaCl}, 20 \mathrm{mM}$ EDTA, $4 \%$ cetrimonium bromide, $1 \%$ polyvinylpyrrolidone, $0.1 \%$ 2-mercaptoethanol). The mixture was beaten for $10 \mathrm{~min}$ using vortex shaker. After $45 \mathrm{~min}$ of incubation in $65{ }^{\circ} \mathrm{C}$ with $0.5 \%$ RNase $\mathrm{A}, 600 \mu \mathrm{L}$ of the chloroform-isoamyl alcohol mixture (24:1) was added and the content was shaken and centrifuged at $14,000 \mathrm{~g}$ for $10 \mathrm{~min}$. The upper phase was transferred into a new tube and mixed with $50 \mu \mathrm{L}$ of buffer II ( $10 \%$ cetrimonium bromide, $0.7 \mathrm{M} \mathrm{NaCl}$ ). The chloroform washing step was repeated. After the addition of cold isopropanol in ratio $1: 1$ the mixture was centrifuged at $14,000 \mathrm{~g}$ for $10 \mathrm{~min}$. The pellet was washed in $500 \mu \mathrm{L}$ of $70 \%$ ethanol and the samples were centrifuged at $14,000 \mathrm{~g}$ for $10 \mathrm{~min}$. The supernatant was discarded, the pellet was dried on air and resuspended in $50 \mu \mathrm{L}$ of nuclease-free water.

Newly designed primers were verified using positive controls: DNA from Anabaena lapponica 966 for cyrB, cyrJ, DNA from Anabaena flos-aquae for anaC, DNA from Microcystis aeruginosa PCC for $m c y B$ and $m y c E$ and DNA from Aphanizomenon flos-aquae NIVACYA 689 for sxt. The negative control was the DNA of Raphidiopsis raciborskii AMU-DH-30 (non-toxic). PCRs for the identification of main genes of cyanotoxins were conducted using Dream Taq DNA polymerase (Thermo Fisher Scientific). Approximately $80 \mathrm{ng}$ of isolated DNA was added to the reaction mixture ( $20 \mu \mathrm{l}$ total volume) with $0.2 \mu \mathrm{M}$ of each primer. PCR was performed with the following parameters: initial denaturation for $3 \mathrm{~min}$ at $95{ }^{\circ} \mathrm{C}, 30$ cycles at $95{ }^{\circ} \mathrm{C}$ for $30 \mathrm{~s}$, a primer-pair specific temperature for $30 \mathrm{~s}$ and $72{ }^{\circ} \mathrm{C}$ for $60 \mathrm{~s}$; a final extension at $72{ }^{\circ} \mathrm{C}$ for $10 \mathrm{~min}$. The electrophoresis of PCR products was conducted on $1 \%$ agarose gels at $100 \mathrm{~V}$ for 25-40 min. Gels were stained with Midori Green Advance DNA Stain (ABO).

\section{HPLC-HRMS}

The high-performance liquid chromatography-high-resolution mass spectrometry (HPLC-HRMS) method was used to detect intra-cellular cyanotoxins in the biomass stored on GF/C filters at $-20^{\circ} \mathrm{C}$ until extraction. Sample preparation included extraction of cyanotoxins with $1 \mathrm{~mL}$ of $75 \%$ methanol in an ultrasonic bath [23]. All chemicals used for analytical procedures were of analytical grades. Acetonitrile (HPLC-grade) and methanol (LiChrosolv hypergrade for LC-MS) were purchased from Merck (Darmstadt, Germany); formic acid (98-100\%) was obtained from Fluka Chemika (Buchs, Switzerland). High-quality water $\left(18.2 \mathrm{M} \Omega \mathrm{cm}^{-1}\right)$ was produced by the Millipore Direct-Q water purification system (Bedford, MA, USA). The MC-LR, MC-RR, MC-YR standards were purchased from Sigma-Aldrich. Sample preparation procedures were run according to Chernova et al. (2016). Analyses of extracts were performed using the LC-20 Prominence HPLC system (Shimadzu, Japan) coupled with LTQ Orbitrap XL Hybrid Ion Trap-Orbitrap Mass Spectrometer (Thermo Fisher Scientific, San Jose, USA). Separation of the toxins was achieved on a Thermo Hypersil Gold RP C18 column $(100 \mathrm{~mm} \times 3 \mathrm{~mm}, 3 \mu \mathrm{m})$ with a Hypersil Gold drop-in guard column (Thermo Fisher Scientific) by gradient elution $\left(0.2 \mathrm{~mL} \mathrm{~min}^{-1}\right)$ with a mixture of water and acetonitrile, both containing $0.05 \%$ formic acid. Mass spectrometric analysis was carried out under conditions of electrospray ionization in the positive ion detection mode. The identification of target compounds was based on the accurate mass measurement of $[\mathrm{M}+\mathrm{H}]^{+}$or $[\mathrm{M}+2 \mathrm{H}]^{2+}$ ions (resolution of 30,000 , accuracy within $5 \mathrm{ppm}$ ), the collected fragmentation spectrum of the ions and the retention times. Limits of the detection for different microcystin congeners $\left(2-6 \mathrm{ng} \mathrm{L}^{-1}\right)$ were evaluated in model experiments using standard compounds, natural water, and biomass as matrixes.

\section{Experimental set-up for treating cyano-HABs}

Experiments on the treatment of Merismopedia sp. bloom in St. George Lake were performed in 250-mL sterile borosilicate glass containers and the oxidants used for this purpose were liquid hydrogen peroxide and metallic peroxide granules. Hydrogen peroxide (30\%) was purchased from Sigma-Aldrich and diluted to $1000 \mathrm{mg}$ $\mathrm{L}^{-1}$ for the stock solution. Calcium peroxide $\left(\mathrm{CaO}_{2}\right)$ and magnesium peroxide $\left(\mathrm{MgO}_{2}\right)$ granules were provided in the form of IXPER ${ }^{\circledR} 70 C G$ and IXPER $^{\circledR}$ Magnesium Peroxide Granules 30MG by Solvay Chimika S.A. (free samples). Bloom sample from St. George Lake was homogenized to achieve similar initial phycocyanin variable fluorescence in each treatment flask ( $8000 \mathrm{RFU})$. $\mathrm{H}_{2} \mathrm{O}_{2}$ stock solution was added into each flask containing raw sample from St. George Lake to achieve the following concentrations: 0 (control), 1, 2, 3, $5 \mathrm{mg} \mathrm{L}^{-1}$; and a quantity calcium peroxide and magnesium peroxide granules to achieve: 0 (control), 1, 2, $3 \mathrm{~g} \mathrm{~L}^{-1}$ granules. All 
the experiments were conducted in a set temperature of $20{ }^{\circ} \mathrm{C}$, and a continuous light of about $800( \pm 200)$ Lux. Each treatment was performed in triplicates.

The oxidant concentration was monitored by the colorimetric method introduced by Sellers et al. (1980) [24]. In brief, $5 \mathrm{~mL}$ of sample was filtered through a PVDF syringe filter and immediately reacted with $0.5 \mathrm{~mL}$ of titanium oxalate $\left([C]=50 \mathrm{~g} \mathrm{~L}^{-1}\right)$ and $0.5 \mathrm{~mL}$ sulfuric acid $(1+17 \mathrm{v} / \mathrm{v})$ (both reagents purchased from SigmaAldrich). Absorbance was then measured at $400 \mathrm{~nm}$ by the Spectroquant ${ }^{\circledR}$ Pharo 300 spectrophotometer in a quartz cuvette and the concentration of $\mathrm{H}_{2} \mathrm{O}_{2}$ was quantified based on a calibration curve ranged between 0.5 and $20 \mathrm{mg} \mathrm{L}^{-1}$.

For determining the efficiency of oxidants on mitigating the naturally occurred cyanobacterial bloom (Merismopedia sp.); photosynthetic changes associated with $\mathrm{H}_{2} \mathrm{O}_{2}$ additions, including instantaneous fluorescence and PSII efficiency were monitored in both wavelengths $(450,620 \mathrm{~nm})$ at $1,2,3,4,6,24,48 \mathrm{~h}$ following oxidant addition. Physicochemical characteristics such as $\mathrm{pH}$, conductivity, TDS and salinity were measured before and after treatment with the use of ExStick probe (EXTECH).

\section{Kinetics release of $\mathrm{H}_{2} \mathrm{O}_{2}$ by metallic peroxide granules}

Kinetics of $\mathrm{H}_{2} \mathrm{O}_{2}$ release were performed in filtered samples of St. George Lake to remove cyanobacterial and other contaminants found in the water. The collected water was filtered through nylon membrane filters $(0.45 \mu \mathrm{m})$ and each flask was filled with $250 \mathrm{~mL}$ of water. $\mathrm{CaO}_{2}$ and $\mathrm{MgO}_{2}$ granules were added into the flask to achieve: 0 (control), 1,2 , and $3 \mathrm{~g} \mathrm{~L}^{-1}$ concentration. $\mathrm{H}_{2} \mathrm{O}_{2}$ concentration was monitored through the colorimetric reaction previously descript for every hour the first $6 \mathrm{~h}$ and then at 24, 26 and $48 \mathrm{~h}$ after the addition of granules in the matrix.

\section{Statistical analyses}

Data processing and statistical analysis was performed with the use of PRISM ${ }^{\circledR}$-GraphPad software. For each measurement, mean and standard deviation of the triplicates were calculated and presented on the graphs as mean with error bar and/or tables as mean \pm SD. Differences of Ft, and $\mathrm{Fv} / \mathrm{Fm}$ between the $\mathrm{H}_{2} \mathrm{O}_{2}, \mathrm{CaO}_{2}$ and $\mathrm{MgO}_{2}$ treatments experiments were compared using one-way ANOVA followed by a Turkey's test.

\section{Results}

\section{Monitoring}

\section{Physicochemical parameters}

During the summer months air temperature was as high as $34{ }^{\circ} \mathrm{C}$ while during Spring, Fall and Winter the temperature varied between $15-25{ }^{\circ} \mathrm{C}$. St. George Lake had a stable $\mathrm{pH}$ with small variations between 8.3 and 8.9 during the year. Throughout the year the conductivity varied between 1200 and $2000 \mu \mathrm{S} \mathrm{cm} \mathrm{cm}^{-1}$ and salinity between 700 and 1000 ppm (Additional file 1: Figure S1). Conductivity and salinity followed the same trend showing a noticeable increase during the summer period; both having their peak in August.

The measured nutrient concentration, calculated dissolved inorganic nitrogen and best fitting ratios for nutrient limitation are summarized in Table 2. Phosphorus was higher than $0.2 \mathrm{mg} \mathrm{L}^{-1}$ in most samples indicating St. George as a eutrophic lake. High nitrogen concentrations were detected in the early months of the year when the status of the lake was oligotrophic with low cyanobacterial content, while high phosphorus concentration was recorded during the blooming period, followed by its decline. Soluble reactive phosphorus (SRP) was below the MDL before the bloom occured, stable during the summer months $(0.03 \mathrm{mg}$ $\mathrm{L}^{-1}$ ) and increased during the remaining monitoring period $\left(0.05 \mathrm{mg} \mathrm{L}^{-1}\right)$. This may be due to heavy rainfalls that caused high nutrient run-offs to enter the lake. Dissolved inorganic nitrogen (DIN) remained high at the beginning of the year, radically decreased during summer, and increased again in winter (Table 1).

The concentration of phosphorus during the bloom was higher than $0.2 \mathrm{mg} \mathrm{L}^{-1}$ which means that in such a eutrophic lake (TP $\left.>0.2 \mathrm{mg} \mathrm{L}^{-1}\right)$ most probably nitrogen became the limiting element. To support these findings, different approaches on estimating nutrient limitation through nutrient ratios (DIN:TP, $\mathrm{NO}_{3}^{-}: \mathrm{TP}$ ) were tested to investigate which one fits better to the studied environment (Table 2). The ratios and thresholds used in the present study for evaluating the trophic status of the lake based on the limiting elements during the monitoring period are presented in Supplementary Materials document.

\section{Photosynthetic parameters and cyanobacterial characterization}

The blooming in St. George Lake was found to be a seasonal phenomenon that peaked during the summer period. More specifically, in July and August 2019 cyanobacterial fluorescence recorded at $620 \mathrm{~nm}$ was extremely high ( $8000 \mathrm{RFU})$ indicating high phycocyanin concentration, but after a light rainfall at the beginning of September it began dropping. Instantaneous fluorescence at $450 \mathrm{~nm}$ corresponding to the chl-a presence in the samples was minimal in the first 3 sampling events, but rapidly increased during blooming and maintained quite high (>1000 RFU) even after blooming period (Fig. 1a). The maximal quantum yield $(\mathrm{Fv} / \mathrm{Fm})$ recorded in both wavelengths $(\lambda=620,450 \mathrm{~nm})$ remained high throughout the year, showing that cyanobacterial mass had a good photosynthetic activity, even before or after blooming, 
as quantum yield is a measure of the PSII efficiency (Fig. 1b).

Microscopic observation of preserved samples during the blooming period showed that $99 \%$ of the phytoplankton biovolume was attributed to a single picocyanobacterial species, Merismopedia sp. (Fig. 2). These species are reported in the literature as microcystin and nodularin producers $[25,26]$, which are both among the most detected cyanotoxin groups in surface waters. Therefore, cyanotoxin genes analyses and cyanotoxin concentrations analysis were performed to examine the toxicity of this bloom.

\section{Cyanotoxins analyses}

The presence of $c y r B$ and $c y r J$ was recorded only in sample 1 . The presence of MC genes was recorded in samples $1(m c y B)$ and 1, 4-8 (mcyE). Neither anaC nor sxtA were found in analyzed samples (Fig. 3).

Because of $m c y B$ and $m c y E$ detection in several samples, the tandem mass spectroscopy (HPLC MS/MS) was employed to verify the presence and concentration of microcystins variants. Microcystins were not detected above the MDL in any of the samples. However, matrix compounds with $\mathrm{m} / z$ very close $(2-4 \mathrm{ppm})$ to that of microcystins were detected in a very low concentration, but the fragmentation patterns of their parent ions differ from those of microcystins (see Additional file 1: Fig. S2). Lack of characteristics fragments for MCs as the $m / z$ $375.27\left[\mathrm{C}_{11} \mathrm{H}_{15} \mathrm{O}\right.$-Glu-Mdha ${ }^{+}, \mathrm{m} / z$ 553.36 [Mdha-AlaLeu-MeAsp-Arg $+\mathrm{H}]^{+}, \quad m / z \quad 599.42 \quad$ [Arg-Adda-Glu] ${ }^{+}$ confirmed the absence of microcystins in the Merismopedia sp. bloom.

Table 1 Primers used in the detection of cyanotoxin producing genes in St. George Lake samples and amplification parameters of PCR

\begin{tabular}{|c|c|c|c|c|c|}
\hline Targeting gene & Primer name & Sequence $5^{\prime}-3^{\prime}$ & $\begin{array}{l}\text { Amplicon } \\
\text { size (bp) }\end{array}$ & $\begin{array}{l}\text { Annealing } \\
\text { temperature }\left({ }^{\circ} \mathrm{C}\right)\end{array}$ & $\begin{array}{l}\text { Reference or source of sequence for } \\
\text { primers design }\end{array}$ \\
\hline \multirow[t]{2}{*}{ cyr」 } & CyrJ_F & AGTAATCCCGCCTGTCATAGA & 109 & 60 & This study; KY550407.1 \\
\hline & cyrJ_R & ACTGAGCATTGTCTCGGTAAAC & & & \\
\hline \multirow[t]{2}{*}{ cyrB } & CyrB_F & GCCTGAGTACCTATCTGCTTAAC & 95 & 60 & This study; EU140798.1 \\
\hline & CyrB_R & AGCCTGAAACTGCTCCATATC & & & \\
\hline \multirow[t]{2}{*}{ sxtA } & SXtA_F & GCGTACATCCAAGCTGGACTCG & 683 & 55 & {$[41]$} \\
\hline & sxtA_R & GTAGTCCAGCTAAGGCACTTGC & & & \\
\hline \multirow[t]{2}{*}{ anac } & anaC_F & TCTGGTATTCAGTCCCCTCTAT & 366 & 58 & {$[42]$} \\
\hline & anaC_R & CCCAATAGCCTGTCATCAA & & & \\
\hline \multirow[t]{2}{*}{$m c y B$} & mcyB_F & CCTCAGACAATCAACGGTTAGT & 119 & 60 & This study; CP020771.1 \\
\hline & mcyB_R & AAAGGCAGAAGGCACCATATAA & & & \\
\hline \multirow[t]{2}{*}{ mCyE } & mcyE_F & CTGGTGGGAAAGGACTGATTTA & 95 & 60 & This study; CP020771.1 \\
\hline & mcyE_R & CGCCCTCAAGTCAAGAAAGA & & & \\
\hline
\end{tabular}

The primers were designed using deposited sequences or taken from references. Cyr, sxt, ana and mcy genes are involved in cylindrospermopsin, saxitoxin, anatoxin and microcystin synthesis, respectively

Table 2 Average total and dissolved nutrient concentration $\left(\mathrm{mg} \mathrm{L}^{-1}\right)$ in St. George Lake during monitoring period, and best fitting nutrient ratios explaining limitation

\begin{tabular}{|c|c|c|c|c|c|c|c|c|c|}
\hline D/M/2019 & TN & TP & $\mathrm{N}-\mathrm{NO}_{3}$ & $\mathrm{~N}-\mathrm{NO}_{2}$ & $\mathrm{~N}-\mathrm{NH}_{4}$ & DIN & DIN:TP & $\mathrm{NO}_{3}{ }^{-}: \mathrm{TP}$ & $\begin{array}{l}\text { Limiting element } \\
\text { Lavine (2001) [30], } \\
\text { Symons (2012) [29] }\end{array}$ \\
\hline $25 / 02$ & 6.0 & 0.06 & 4.6 & 0.10 & 0.10 & 4.8 & 80 & 77 & $P$ \\
\hline 04/03 & 4.7 & 0.11 & 3.4 & 0.09 & 0.10 & 3.6 & 33 & 31 & $P$ \\
\hline $18 / 04$ & 6.9 & 0.06 & 5.8 & 0.11 & 0.10 & 6.0 & 100 & 97 & $P$ \\
\hline $12 / 07$ & 6.6 & 0.20 & 2.4 & 0.08 & 0.20 & 2.7 & 13 & 12 & Co-limitation \\
\hline 06/08 & 7.9 & 0.36 & 0.0 & 0.08 & 0.29 & 0.4 & 1 & 0 & $\mathrm{~N}$ \\
\hline $22 / 08$ & 2.6 & 0.28 & 1.9 & 0.06 & 0.13 & 2.1 & 7 & 7 & $\mathrm{~N}$ \\
\hline 09/09 & 5.3 & 0.19 & 0.0 & 0.14 & 0.94 & 1.1 & 6 & 0 & $\mathrm{~N}$ \\
\hline $15 / 10$ & 4.1 & 0.14 & 1.8 & 0.08 & 0.10 & 2.0 & 14 & 13 & Co-limitation \\
\hline 09/12 & 6.4 & 0.28 & 4.9 & 0.09 & 0.10 & 5.1 & 18 & 18 & Co-limitation \\
\hline
\end{tabular}




\section{Treatments}

The oxidants used for cyano-HAB mitigation exhibited different efficiencies and impact on the Merismopedia sp. bloom. The average initial instantaneous fluorescence (Ft) and quantum yield at $\lambda=620 \mathrm{~nm}$, were 8500 and 0.37 , respectively; while at $\lambda=450 \mathrm{~nm}$ were 3000 and 0.6 , respectively. Liquid hydrogen peroxide was not effective for treating the dense bloom in concentrations of $1-5 \mathrm{mg}$ $\mathrm{L}^{-1}$.

At the lowest doses ( 1 and $\left.2 \mathrm{mg} \mathrm{L}^{-1}\right)$ cyanobacteria continued to grow steadily; making the treatment inefficient. Treatment with 3 and $5 \mathrm{mg} \mathrm{L}{ }^{-1} \mathrm{H}_{2} \mathrm{O}_{2}$ showed only a minor drop of the corresponding $\mathrm{Ft}$ values in raw fluorescence units (RFU) compared with the control (Fig. 4a) which was found to be insignificant $(p>0.05)$. All treated samples showed a stable average of QY around 0.37 , meaning that the bloom remained unaffected during treatment with liquid $\mathrm{H}_{2} \mathrm{O}_{2}$ and the oxidant dose was unable to disrupt the photosystem II efficiency (Fig. 4b) of the specific bloom.

Treatment with $\mathrm{CaO}_{2}$ granules effectively decreased the photosynthetic activity of cyanobacteria (Fig. 5a). $\mathrm{CaO}_{2}$ doses of 2 and $3 \mathrm{~g} \mathrm{~L}^{-1}$ significantly decreased the pigment concentration measured as Ft value after only $24 \mathrm{~h}$ $\left(p<0.001\right.$ compared to control and $\left.1 \mathrm{~g} \mathrm{~L}^{-1}\right)$ and maintained at low levels until $48 \mathrm{~h}$ of treatment. Even though $2 \mathrm{~g} \mathrm{~L}^{-1}$ of $\mathrm{CaO}_{2}$ reduced the sample's fluorescence, $\mathrm{Fm} /$ Fv was restored after $6 \mathrm{~h}$ of treatment, making it less efficient than $3 \mathrm{~g} \mathrm{~L}^{-1}$ which maintained a lower $\mathrm{Fm} / \mathrm{Fv}$ value for the duration of the 48-h treatment (Fig. 5b).

Magnesium peroxide treatment was inefficient for concentrations up to $3 \mathrm{~g} \mathrm{~L}^{-1}$. Both $\mathrm{Ft}$ and $\mathrm{Fv} / \mathrm{Fm}$ values at $\lambda=620 \mathrm{~nm}$ were stable during the treatment period (Fig. 6). In the first $4 \mathrm{~h}$ of treatment, Ft values insignificantly decreased, but then were recovered within $6 \mathrm{~h}$ of treatment. In general, magnesium peroxide was not able

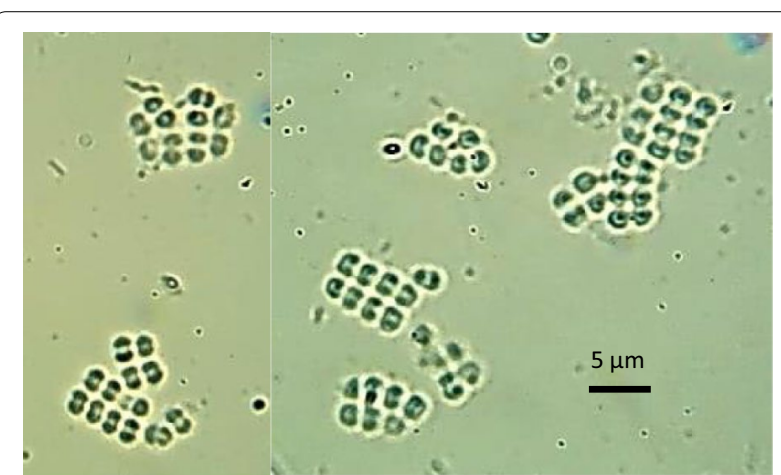

Fig. 2 Merismopedia sp. captured under ECLIPSE Ci-L microscope equipped with OPTIKAM Wi-Fi camera with magnification 100x

to influence the bloom, and therefore had no effect on both Ft and Qy.

Fluorescence and maximal quantum efficiency of PSII at $450 \mathrm{~nm}$ excitation wavelength were also monitored during the $48 \mathrm{~h}$ treatment, to examine the effect of oxidants in the chlorophyll-a concentration, as illustrated in Fig. $7 \mathrm{a}-\mathrm{f}$. There was a drop of chl-a in samples treated with 3 and $5 \mathrm{mg} \mathrm{L}^{-1}$ of $\mathrm{H}_{2} \mathrm{O}_{2}$, giving also visual changes in the color of the treated water. Even though chl-a concentration (measured in RFU) dropped at the high added $\mathrm{H}_{2} \mathrm{O}_{2}$ concentrations, QY was stable in all samples during treatment meaning that PSII photosynthetic activity was not affected during treatment (Fig. 7a, b). Instantaneous fluorescence, measured at $450 \mathrm{~nm}$ of samples treated with 2 and $3 \mathrm{~g} \mathrm{~L}^{-1} \mathrm{CaO}_{2}$, showed significant drop of about $50 \%$ $(p<0.05$ in comparison with control), while the quantum yield of the same samples was not significantly affected, meaning that recorded chl-a could be extracellular due to cell destruction during treatment (Fig. 7c, d). Magnesium peroxide treatment was inefficient for all added doses.
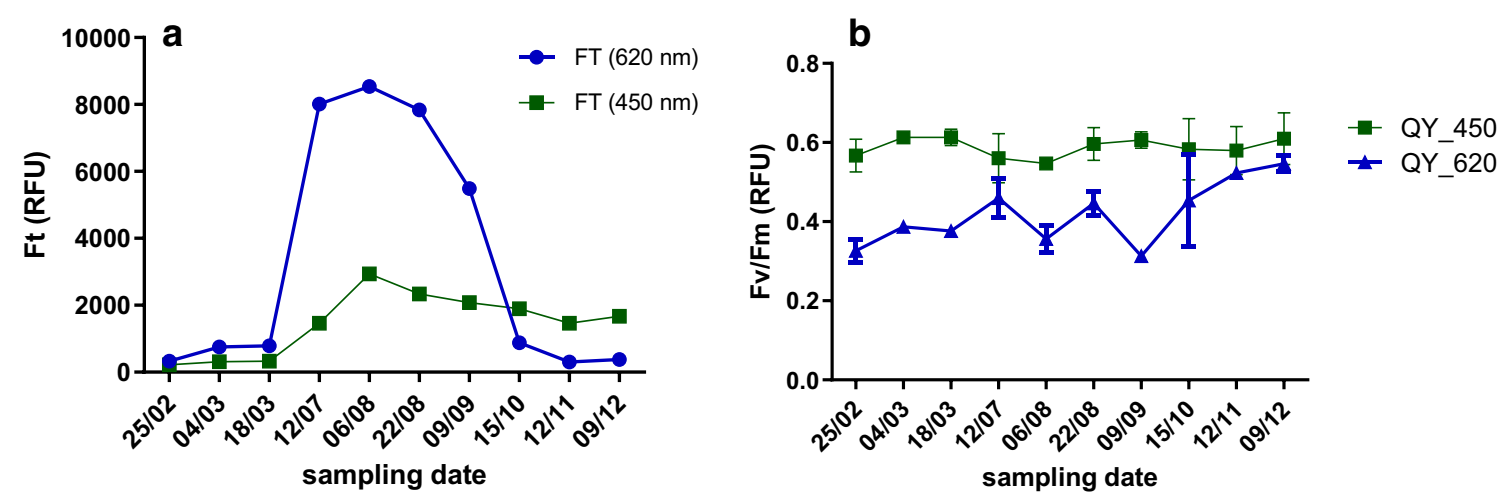

Fig. 1 a Instantaneous fluorescence (Ft) in raw fluorescence units and $\mathbf{b}$ quantum yield measurements for phycocyanin (620 nm excitation) and chlorophyll-a (450 nm excitation) in St. George Lake samples during monitoring period (mean \pm SD) 

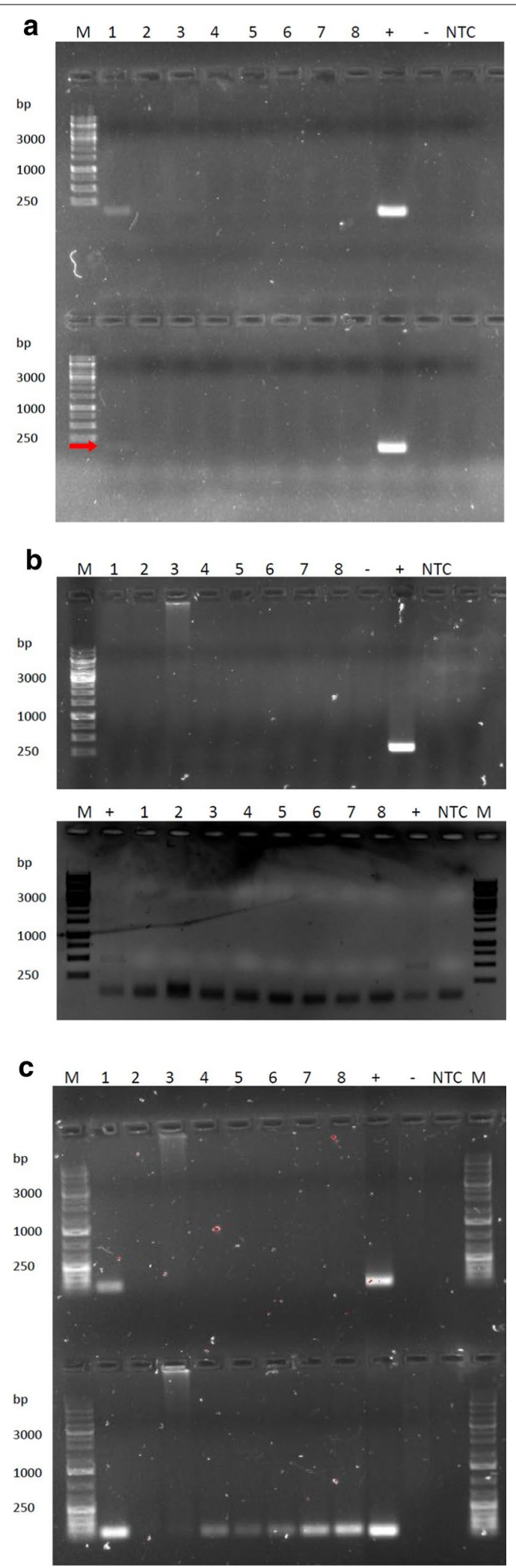

Fig. 3 Agarose gel electrophoresis of DNA extracted from St. George Lake samples: a cyrB (upper row) and cyrs (lower row); anaC (upper row) and sxtA (lower row); c $m c y B$ (upper row) and $m c y E$ (lower row). $M$ means marker, numbers 1-8 are the samples from St. George Lake, (+) positive control, (-) negative control, NTC (non-template control) is the control without DA

Both $\mathrm{Ft}$ and $\mathrm{Fv} / \mathrm{Fm}$ values at $450 \mathrm{~nm}$ were stable during the treatment period (Fig. 7e, f).

It is apparent that $\mathrm{MgO}_{2}$ had a much lower $\mathrm{H}_{2} \mathrm{O}_{2}$ releasing capacity than $\mathrm{CaO}_{2}$, making $\mathrm{CaO}_{2}$ a much more efficient treatment method. Release curves in filtered St. George Lake matrix showed that maximum accumulative hydrogen peroxide concentration from 1,2 and $3 \mathrm{~g} \mathrm{~L}^{-1}$ of $\mathrm{CaO}_{2}$ was $3.5,8.0$ and $11 \mathrm{mg} \mathrm{L}^{-1}$, respectively; while for 1,2 and $3 \mathrm{~g} \mathrm{~L}^{-1}$ of $\mathrm{MgO}_{2}$ it was $0.7,1.2$, and $1.8 \mathrm{mg} \mathrm{L}^{-1}$ of $\mathrm{H}_{2} \mathrm{O}_{2}$, respectively (Fig. 8). Even though a noticeable amount of $\mathrm{H}_{2} \mathrm{O}_{2}$ was released in filtered water by granules; during treatment, oxidant was rapidly consumed throughout treatment as we were unable to detect any residual concentrations higher than $0.5 \mathrm{mg} \mathrm{L}^{-1}$.

Physicochemical parameters ( $\mathrm{pH}$, conductivity, Salinity and TDS) variations during the treatments were monitored since the treatment with oxidants may negatively affect water matrixes. Hydrogen peroxide did not affect the water quality characteristics while magnesium peroxide granules slightly increased all the recorded parameters. $\mathrm{MgO}_{2}$ and $\mathrm{CaO}_{2}$ granules made the solution more alkaline while $\mathrm{H}_{2} \mathrm{O}_{2}$ had the least effect on the $\mathrm{pH}$ of the water matrix (Fig. 9). More specifically, $3 \mathrm{~g} \mathrm{~L}^{-1} \mathrm{CaO}_{2}$ granules increased the $\mathrm{pH}$ above 10 , which is considered high for freshwater environments. Overall, there was no dramatic change of the physicochemical characteristics of the water, except the $\mathrm{pH}$ rise above 10 which is considered as an unwanted effect in the waterbody.

\section{Discussion \\ Monitoring}

Monitoring of St. George Lake showed that the blooming period lasted 4 months during summer and early autumn period (June-September). The increase of the water temperature and the low turbidity during summer in combination with nutrient load and/or release from the sediments [27] may result in periodical blooming of cyanobacteria. In St. George Lake, high nutrient content recorded throughout the year, favored Merismopedia sp. to form mono-dominated dense bloom. Annual average of nutrients classifies this Lake at class III (see OECD classification in additional materials document, Additional file 1: Table S2) meaning that water quality improvements are essential to be applied since EU Water Framework Directive requested member countries to maintain surface waters at class I and II [28]. 

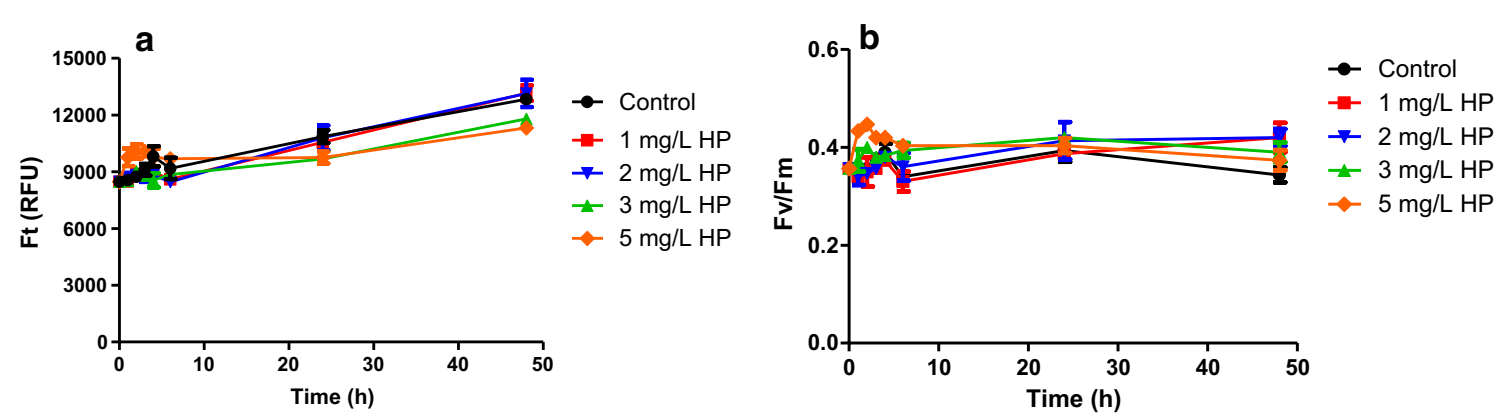

Fig. 4 The effect of liquid $\mathrm{H}_{2} \mathrm{O}_{2}$ concentration $\left(0,1,2,3,5 \mathrm{mg} \mathrm{L}^{-1}\right)$ on a phycocyanin concentration (measured as raw fluorescence units-RFU) and b maximal quantum efficiency of the PSII (QY) at $620 \mathrm{~nm}$. Results are expressed as the mean \pm SD
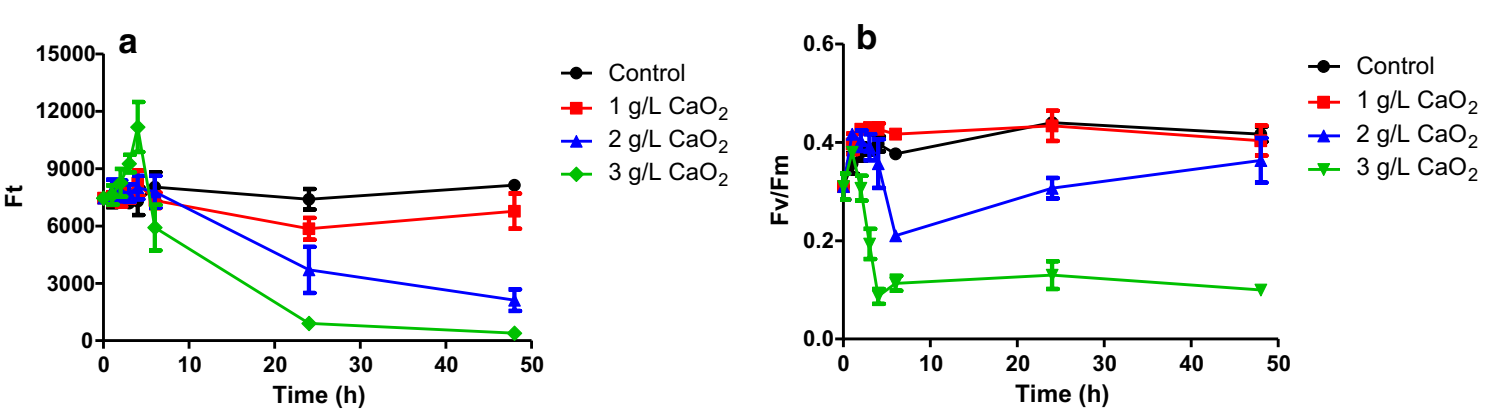

Fig. 5 The effect of calcium peroxide granules concentration $\left(0,1,2,3 \mathrm{~g} \mathrm{~L}^{-1}\right)$ on a phycocyanin concentration (measured as raw fluorescence units-RFU) and $\mathbf{b}$ maximal quantum efficiency of the PSII (QY) at $620 \mathrm{~nm}$. Results are expressed as the mean \pm SD
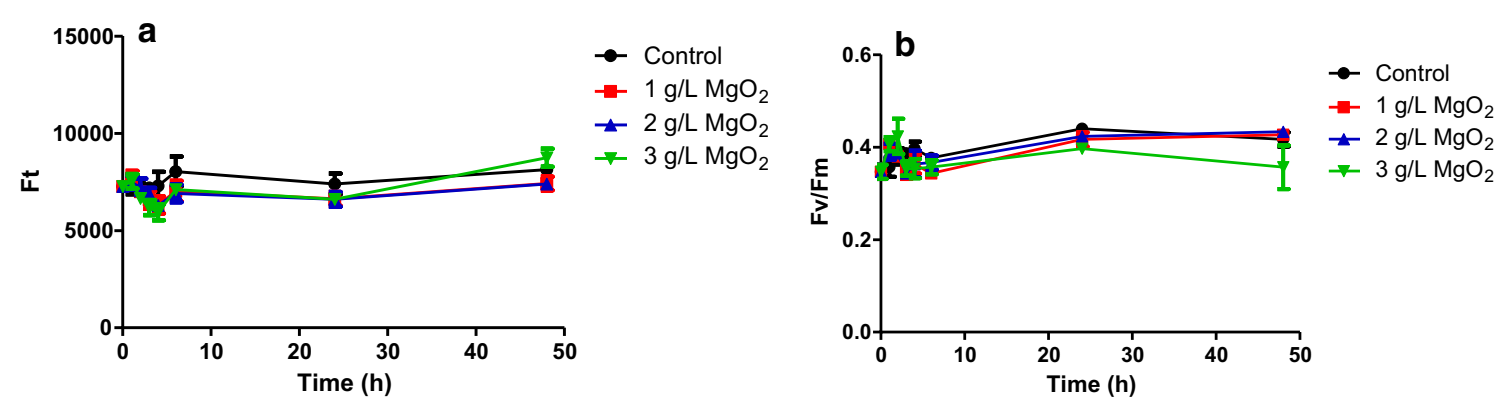

Fig. 6 The effect of magnesium peroxide granules concentration $\left(0,1,2,3 \mathrm{~g} \mathrm{~L}^{-1}\right)$ on a phycocyanin concentration (measured as raw fluorescence units-RFU) and $\mathbf{b}$ maximal quantum efficiency of the PSII (QY) at $620 \mathrm{~nm}$. Results are expressed as the mean \pm SD

Guildford and Hecky (2000) proposed that lake systems tend to have higher than Redfield thresholds for P-limitation [29]. Those thresholds showed a better fit than TN:TP molar ratios, shifting from P-limitation to co-limitation during the bloom, but they still do not represent well the trophic status. The best fit was found when the ratio proposed by Levine (2001) and Symons (2012) [30, 31] was applied (Table 2). Both DIN:TP and $\mathrm{NO}_{3}{ }^{-}$:TP mass ratios showed relatively similar results, suggesting
$\mathrm{N}$-limitation during the bloom, co-limitation before and after the bloom and P-limitation in the remaining period. Overall, approaches that were based on ocean dynamics were found to have poor fitting on the trophic status of the lake in contrast with more recent approaches that were intended for fresh waterbodies. This stresses the need of better understanding nutrient dynamics in lakes and the development of holistic approaches based on the different physicochemical characteristics of each 


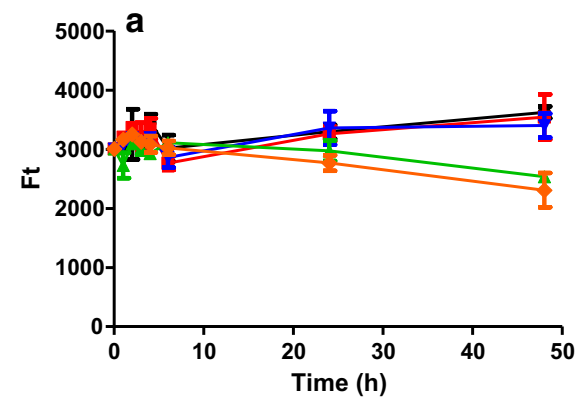

- Control

- $1 \mathrm{mg} / \mathrm{L} \mathrm{HP}$

$\rightarrow 2 \mathrm{mg} / \mathrm{L} \mathrm{HP}$

$-3 \mathrm{mg} / \mathrm{L} \mathrm{HP}$

$\diamond 5 \mathrm{mg} / \mathrm{L} \mathrm{HP}$
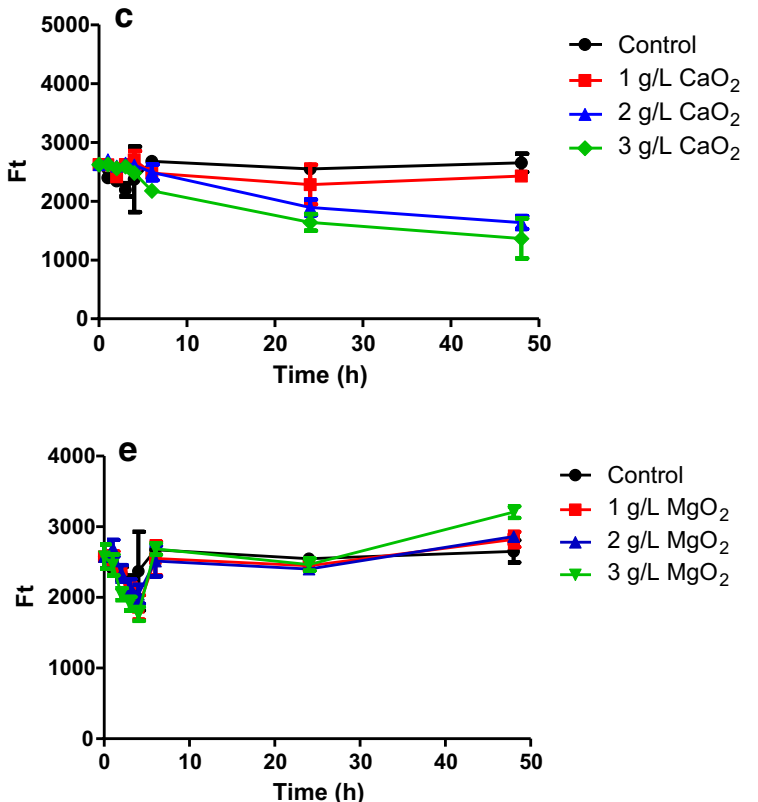

Control

$1 \mathrm{~g} / \mathrm{L} \mathrm{MgO}$

$+2 \mathrm{~g} / \mathrm{L} \mathrm{MgO}_{2}$

$\rightarrow 3 \mathrm{~g} / \mathrm{LMOO}_{2}$
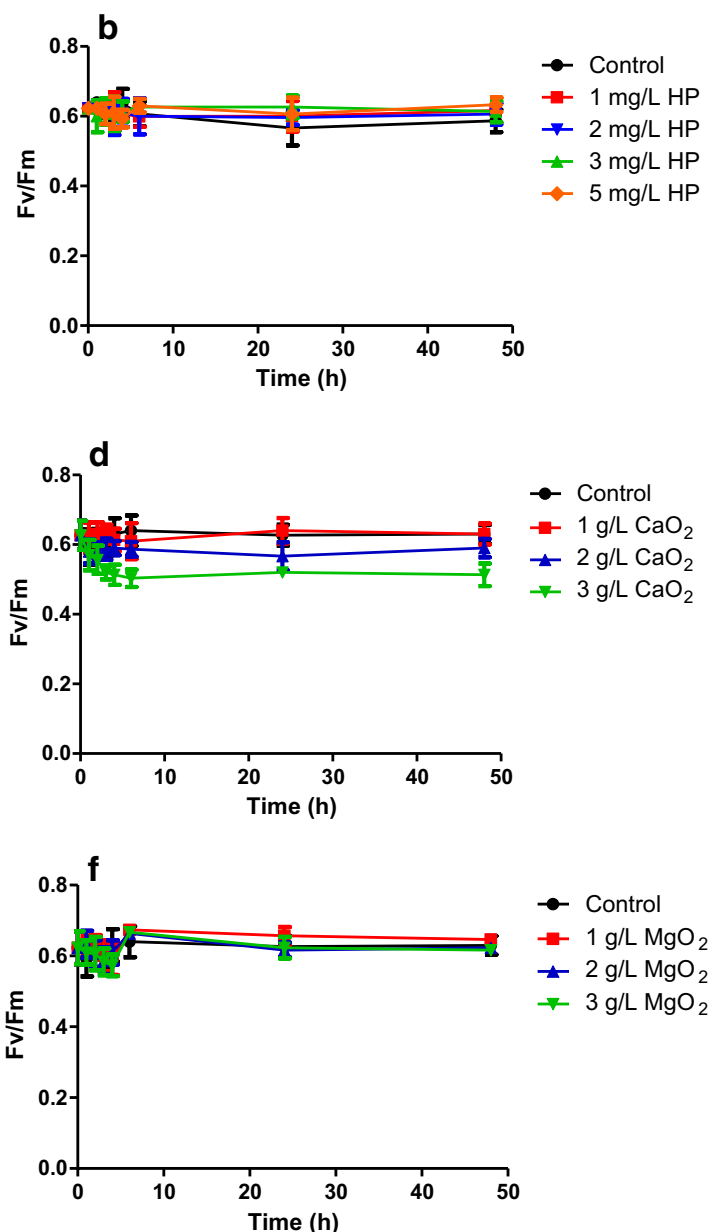

Fig. 7 Instantaneous fluorescence (Ft) and photosynthetic quantum yield ( $\mathrm{Fv} / \mathrm{Fm}$ ) at $450 \mathrm{~nm}$ for treatment with: $\mathbf{a}, \mathbf{b} \mathrm{H}_{2} \mathrm{O}_{2} 1-5 \mathrm{mg} \mathrm{L}^{-1} ; \mathbf{c}$, d CaO${ }_{2}$ $1-3 \mathrm{~g} \mathrm{~L}^{-1}$, and $\mathbf{e}, \mathbf{f} \mathrm{MgO}_{2} 1-3 \mathrm{~g} \mathrm{~L}^{-1}$

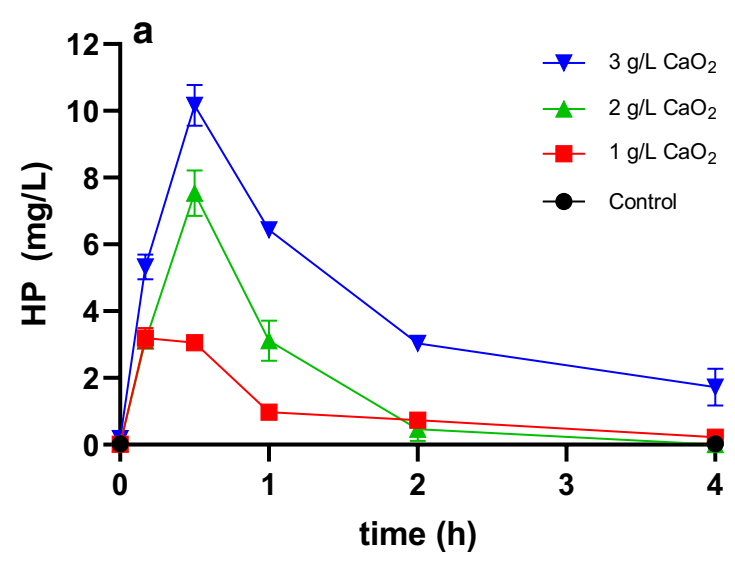

b

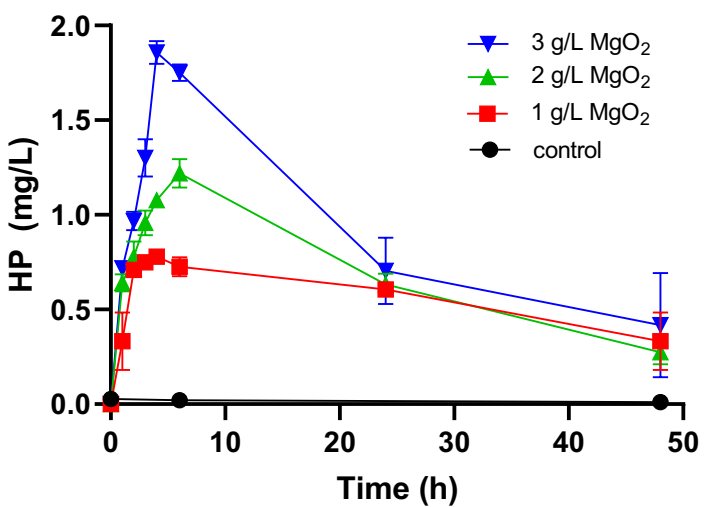

Fig. 8 Kinetic release curves of $\mathrm{H}_{2} \mathrm{O}_{2}$ from 1,2 and $3 \mathrm{~g} \mathrm{~L}^{-1}$ of $\mathbf{a} \mathrm{CaO}_{2}$ and $\mathbf{b} \mathrm{MgO}_{2}$ peroxide granules in filtered St. George Lake water 


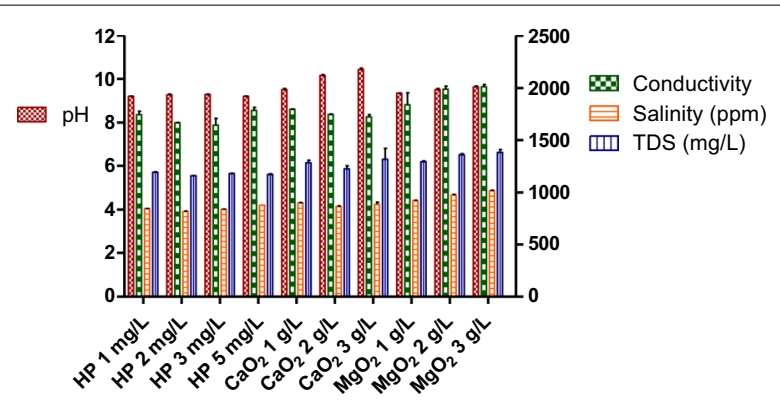

Fig. 9 Average $\mathrm{pH}$, conductivity, salinity and TDS (mean \pm SD) of St. George Lake water $\left(\mathrm{pH}=8.88\right.$, conductivity $=1999 \mu \mathrm{S} \mathrm{cm}{ }^{-1}$, salinity $=1015 \mathrm{ppm}$ ) after $48 \mathrm{~h}$ of treatment with liquid $\mathrm{H}_{2} \mathrm{O}_{2}, \mathrm{CaO}_{2}$ and $\mathrm{MgO}_{2}$ granules

waterbody, taking into consideration also other limiting factors that may affect trophic status, such as light intensity and temperature [32].

High correlation of nutrient levels and trophic status indicates the need of monitoring for the early detection of (toxic) cyanobacterial blooms when a high nutrient load is documented. Photosynthetic parameters of water samples such as instantaneous fluorescence and PSII quantum yield are strong indicators of the bloom density. Instantaneous fluorescence $(\mathrm{Ft})$ of water samples at $620 \mathrm{~nm}$ with higher than $3000 \mathrm{RFU}$ usually represents an on-going bloom or a preliminary stage of a bloom. A steep increase of fluorescence at $620 \mathrm{~nm}$, revealed the increase of cyanobacterial mass into the water since it represents phycocyanin, a pigment found in cyanobacteria. Also, an increase at $450 \mathrm{~nm}$ confirmed chlorophyll-a presence which is also a pigment found in both cyanobacterial cells and green-algae suspensions. Ft in raw fluorescence units remained high even after the bloom. This can be explained with the release of pigments after the cell death occurred at the end of the blooming period and gave high fluorescence signal both at $620 \mathrm{~nm}$ (phycocyanin) and $450 \mathrm{~nm}$ (chlorophyll-a). Another possibility is the growth of green-algae after the cyanobacterial blooming cycle that gave a high chl-a fluorescence signal.

Microscopic observation of samples during the bloom indicated a mono-domination of a picocyanobacterial species Merismopedia (most probably Merismopedia minutissima based on their 2-D sheets morphology), a known MC and NOD producer. However, even though genes involved in MC and NOD synthesis were present (mcyB and $m c y E$ ), these cyanotoxins were not detectable in any sample. This may indicate that the gene expression was weak, and the toxin level was below the method detection limit. The regulation of $m c y$ gene expression in a response to external biotic and abiotic factors has been investigated recently [33]. An indirect downregulation of MC synthesis was observed in response to iron limitation [34], probably as a result of a lower photosynthetic activity. The light intensity is also known as an important abiotic factor influencing $m c y$ expression and $\mathrm{MC}$ production [35]. Interestingly, in mixed cultures of $M$. aeruginosa and $P$. agardhii both suppressed growth and downregulation of $m c y E$ expression were observed [36] which suggested that the competition between two toxic strains may result in a lower MC production. In the studied lake, the mono-domination of one species excluded a strong competition with other species and we can only hypothesize that in this condition MC production was also inhibited. Alternatively, the presence of $m c y B$ only in 1 sample and $m c y E$ in 6 samples may indicate that the genetic machinery for $\mathrm{MC}$ synthesis is deficient and the dominant species lost the capability of MC synthesis.

However, it should be underlined that any applied genetic method should be complemented and accompanied with an analytical confirmation. The level of $m c y$ transcripts is often not correlated with the MC concentration. The toxicity based on the mcy levels might be both under- and overestimated [37, 38] . Therefore, these assays should not be considered as good indicators of bloom toxicity, but rather as a complementary tool in risk assessments. Similarly, it can be assumed that the detection of $m c y$ does not ensure MC presence, which should be proven through advanced analytical methods (LC-MS/MS). Attention should be paid on the obtained $\mathrm{m} / z$ and the corresponding fragmentation patterns so that cyanotoxin concentration is not overestimated.

\section{Treatment}

Dense blooms of Merismopedia sp. in a eutrophic lake inferred the requirement of extremely high doses of $\mathrm{H}_{2} \mathrm{O}_{2}$ for efficient treatment. Since in those cases, direct application of $\mathrm{H}_{2} \mathrm{O}_{2}$ doses over $5 \mathrm{mg} \mathrm{L}^{-1}$ are considered potentially harmful for the other components of microbial communities (bacteria, phytoplankton, and zooplankton), alternative solutions are needed. $\mathrm{CaO}_{2}$ and $\mathrm{MgO}_{2}$ granules studied herein, are an alternative to the traditionally used liquid hydrogen peroxide [39]. To determine the most efficient dose, we took into consideration the ability of the oxidant to destroy cyanobacterial cells by measuring changes in the photosynthetic parameters such as fluorescence of the pigments (phycocyanin and chl-a) and the maximal efficiency of the PSII quantum yield, as well as the effects that it may had on the physicochemical parameters of the sample $(\mathrm{pH}$, conductivity, TDS, and salinity). 
Treatment with 2 and $3 \mathrm{~g} \mathrm{~L}^{-1}$ of $\mathrm{CaO}_{2}$ treatment were the most effective in bloom elimination (Figs. 4, 6), but they both caused an increase of $\mathrm{pH}$ which recorded slightly above 10 after 48 -h of treatment (Fig. 9). Taking into consideration the wellness of the photosystem II, recorded as the quantum yield, $2 \mathrm{~g} \mathrm{~L}^{-1} \mathrm{CaO}_{2}$ did not affect QY significantly, which means that photosynthetic activity of treated sample may be restored shortly after treatment allowing for further growth of the remaining healthy cells. On the other hand, treatment with $\mathrm{CaO}_{2} 3 \mathrm{~g}$ $\mathrm{L}^{-1}$ outperformed other concentrations as it maintained a low Fv/Fm $(<0.2)$ for up to 48-h. Also, a drop of the Ft at $\lambda=450 \mathrm{~nm}$ (chl-a fluorescence) reflects the ability of $\mathrm{H}_{2} \mathrm{O}_{2}$, released by 2 and $3 \mathrm{~g} \mathrm{~L}^{-1} \mathrm{CaO}_{2}$, to degrade not only the cyanobacterial cells, but also part of the pigmentation released by cyanobacteria after cell death. In the rest of the treatments, where chl-a fluorescence was not affected significantly $(p>0.05)$, residual $\mathrm{H}_{2} \mathrm{O}_{2}$ concentration was not high enough to cause the simultaneous degradation of cyanobacteria and released pigments at the same time.

Both granules released $\mathrm{H}_{2} \mathrm{O}_{2}$ with a reaction that follows a pseudo-zero-order kinetics pattern, and their kinetics are greatly affected by temperature and the $\mathrm{pH}$ of the solution as explained by Wang et al. [21]. In general, $\mathrm{CaO}_{2}$ shows higher releasing capacity than $\mathrm{MgO}_{2}$ (Fig. 8). The lower $\mathrm{H}_{2} \mathrm{O}_{2}$ release by $\mathrm{MgO}_{2}$ may be due to the fact that, at the same $\mathrm{pH}$, the dissolution product of $\mathrm{MgO}_{2}$, (magnesium hydroxide) is less soluble than the dissolution product of $\mathrm{CaO}_{2}$ (calcium hydroxide) not allowing for the reaction equilibrium to shift towards the products. This also affected the suspended solids content of the treated water. Calcium peroxide granules caused drastic change of $\mathrm{pH}$ as while decomposing it releases highly basic $\mathrm{Ca}(\mathrm{OH})_{2}$ (Eqs. 1, 2).

Taking into consideration both the treatment efficiency and the releasing capacity, direct application of liquid $\mathrm{H}_{2} \mathrm{O}_{2}$ and $\mathrm{MgO}_{2}$ granules is less efficient compared with $\mathrm{CaO}_{2}$ granules. For the effective restoration of contaminated sites by high-density cyanobacterial blooms, doses higher than $5 \mathrm{mg} \mathrm{L}^{-1}$ of liquid $\mathrm{H}_{2} \mathrm{O}_{2}$ should be applied and in the case of magnesium peroxide granules it would require higher than $3 \mathrm{~g} \mathrm{~L}^{-1}$ of granular compound. In both cases the required applied doses will have undesirable side-effects for in situ application. Therefore, $\mathrm{CaO}_{2}$ which has the ability to release $\mathrm{H}_{2} \mathrm{O}_{2}$ more effectively could be introduced as a suitable treatment methods in concentrations no more than $3 \mathrm{~g} \mathrm{~L}^{-1}$ for high-density blooms. Effects on the physicochemical parameters of treated freshwaters need to be accounted as well when deciding on the type of oxidant and its dosing to avoid possible side-effects in the lake during treatment.

\section{Conclusions}

Conventional monitoring tools can give limited information on the factors driving cyanobacterial blooming. Therefore, additional characterization of the lake ecosystem including physicochemical characteristics; total and dissolved nutrients; temperature, air and light intensity; cyanobacterial and green algae content; cyanotoxins genes, and cyanotoxins analyses were found to be essential. Correlations between nutrients and eutrophication have been developed recently [40] with the DIN:TP and $\mathrm{NO}_{3}{ }^{-}$:TP mass ratio to be the most promising ratios for shallow lake systems, as confirmed also in our case. While these ratios are proving to be promising for understanding the eutrophic status of surface waters, they should be applied after careful examination of each waterbody's unique characteristics. Customized monitoring strategies for each waterbody and treatment application at the early stages of a bloom, are essential for protecting water quality of surface waters.

Treating cyanobacteria effectively, without harming the remaining ecosystem is vital for restoring and safeguarding surface water quality. Currently, hydrogen peroxide is widely used for mitigating cyano-HABs as an alternative to algicides and an eco-friendly method. However, the treatment of dense blooms, such as the one occurred in St. George Lake, requires the application of high doses $\left(>5 \mathrm{mg} \mathrm{L}^{-1}\right)$ of liquid $\mathrm{H}_{2} \mathrm{O}_{2}$ at once which in turn affects other aquatic organisms in the lake. This means that application of liquid hydrogen peroxide must be performed on low biomasses, at the beginning of a bloom cycle and not on high-density blooms to avoid the undesirable side-effects, including the release of potential cyanotoxins into the waterbody. Therefore, peroxide granules that are $\mathrm{H}_{2} \mathrm{O}_{2}$ slow releasing oxidants were tested herein as an alternative to a single-dosed liquid hydrogen peroxide treatment. Despite that concentrations of $\mathrm{CaO}_{2}$ granules higher than $2 \mathrm{~g} \mathrm{~L}^{-1}$ can release a high amount of $\mathrm{H}_{2} \mathrm{O}_{2}\left(>10 \mathrm{mg} \mathrm{L}^{-1}\right), \mathrm{CaO}_{2}$ granules act gradually by first reacting with the organic load of the matrix and then by reaching the contaminant making it more efficient than liquid hydrogen peroxide. Calcium peroxide outperformed magnesium peroxide in terms of treating contaminated water samples, which makes it a potential treatment method worth investigating further for its efficiency on different cyanobacterial species and matrixes.

Based on the above, bloom mitigation with $\mathrm{CaO}_{2}$ granules (as an alternative to liquid $\mathrm{H}_{2} \mathrm{O}_{2}$ ) must be first validated in bench-scale experiments to adjust the appropriate doses based on the waterbody needs (type of bloom, density, water quality characteristics). Benchscale evaluation of an emerging treatment method provides important information towards its optimization, 
however it is important to investigate its scalability potential as well [20]. In the case of peroxide granules, care should be taken with the way they are applied in the field since based on their size, they can be consumed by aquatic organisms prior to their degradation. Application through a delivery system can be one way of resolving this problem. Further studies will provide a clearer view on its potential as a promising mitigation technique and allow for its application as an effective, yet green treatment option.

\begin{abstract}
Abbreviations
Cyano-HABs: Cyanobacteria harmful algal blooms; TN: Total nitrogen; TP: Total phosphorus; DIN: Dissolved inorganic nitrogen; SRP: Soluble reactive phosphorus; TDS: Total dissolved solids; MDL: Method detection limit; OECD: Organisation of Economic Co-operation and Development; EC: European Commission; EU: European Union; mg: Milligram; $\mu \mathrm{g}$ : Microgram; ng: Nanograms; $\mu$ S: Micro-siemens; $\mu \mathrm{m}$ : Micrometer; cm: Centimeter; nm: Nanometer; mL: Milliliter; L: Liter; g: Grams; h: Hours; ppm: Parts per million; St. George: Saint George; ANFP: Athalassa National Forest Park; sp.: Species; $\mathrm{H}_{2} \mathrm{O}_{2}$ : Hydrogen peroxide; $\mathrm{CaO}_{2}$ : Calcium peroxide; $\mathrm{MgO}_{2}$ : Magnesium peroxide; $\mathrm{MC}$ : Microcystins; NOD: Nodularins; QY: Quantum yield (QY=Fv/Fm); Ft: Instantaneous fluorescence (RFU); $\lambda$ : Wavelength; P: Phosphorus; N: Nitrogen.
\end{abstract}

\section{Supplementary Information}

The online version contains supplementary material available at https://doi. org/10.1186/s12302-021-00471-5.

Additional file 1. Additional figures and tables.

\section{Acknowledgments}

The CUT authors are thankful to the Department of Forestry for granting access in the lakes for sampling purposes and their assistance during sampling events. We would like to thank the journal reviewers for their insightful input and for helping us improve significantly the manuscript.

\section{Authors' contributions}

EK worked on the development of the experimental design for the monitoring and treatment under the guidance of MGA; EK performed monitoring and cyano-HABs treatment and initiated the first draft of the manuscript; CP performed cyano-HABs treatment experiments under the supervision of MGA and EK; ASo was the technician responsible for the water sampling events; ASu was involved in initial sampling events and he trained the researchers on the handling of lake samples and photosynthetic activity measurements with AP-100C; DD was responsible for the cyanotoxins genes analyses; EC performed HPLC-HRMS for cyanotoxins analysis; LB contributed to the cyanobacteria species characterization; and MGA led the research efforts on monitoring and treatment of St. George Lake. All authors read and approved the final manuscript.

\section{Funding}

This work funded by the Cyprus Seeds organization under the project "Novel physico-chemical oxidation processes for mitigating toxic cyanobacterial blooming". The project was also supported by the CYANOS project funded from the Research Innovation Foundation (BILATERAL/FRANCE/1116/0006) that covered traveling expenses to and from the University of Rennes in France for performing phytoplankton characterization of St. George Lake water samples.

\section{Availability of data and materials}

Not applicable.

\section{Declarations}

Ethics approval and consent to participate

Not applicable.

\section{Consent for publication}

Not applicable.

\section{Competing interests}

The authors declare that they have no competing interests.

\section{Author details}

${ }^{1}$ Department of Chemical Engineering, Cyprus University of Technology, 3036 Lemesos, Cyprus. ${ }^{2}$ The Yigal Allon Kinneret Limnological Laboratory, Israel Oceanographic and Limnological Research, Migdal, Israel. ${ }^{3}$ Laboratory of Metabolomics, Department of Microbiology, Faculty of Biochemistry, Biophysics and Biotechnology, Jagiellonian University, Gronostajowa 7, 30387 Krakow, Poland. ${ }^{4}$ St. Petersburg Federal Research Center of the Russian Academy of Sciences (SPC RAS), Scientific Research Centre for Ecological Safety of the Russian Academy of Sciences, 18, Korpusnaya st, Saint Petersburg 197110, Russia. ${ }^{5}$ UMR 6553 Centre National de La Recherche Scientifique ECOBIO/OSUR, University of Rennes 1, Rennes, France.

Received: 11 December 2020 Accepted: 26 February 2021

Published online: 12 March 2021

\section{References}

1. Altermann W, Kazmierczak J, Oren A, Wright DT (2006) Cyanobacterial calcification in Earth history Cyanobacterial calcification and its rockbuilding potential during 3.5 billion years of Earth history. Geobiology 4:147-166

2. Jakubowska N, Szeląg-Wasielewska E (2015) Toxic Picoplanktonic Cyanobacteria-Review. Mar Drugs 13:1497-1518

3. Thomas J (1972) Relationship between age of culture and occurrence of the pigments of photosystem II of photosynthesis in heterocysts of a blue-green alga. J Bacteriol 110:92-95

4. Moss B, Jeppesen E, Sondergaard M, Lauridsen TL, Liu ZW (2013) Nitrogen, Macrophytes, shallow lakes and nutrient limitation: resolution of a current controversy? Hydrobiologia 710(1):3-21

5. Bachmann RW, Jones BL, Fox DD, Hoyer M, Bull LA, Canfield DE (1996) Relations between trophic state indicators and fish in Florida (USA) lakes. Can J Fish Aquat Sci 53(4):842-855

6. Krztoń W, Kosiba J, Pociecha A et al (2019) The effect of cyanobacterial blooms on bio- and functional diversity of zooplankton communities. Biodivers Conserv 28:1815-1835

7. Meriluoto J, Spoof L, Codd GA (eds) (2017) Handbook of Cyanobacterial Monitoring and Cyanotoxin Analysis. Wiley, Chichester

8. Souza NR, Metcalf JS (2020) Cyanobacterial toxins and their effects on human and animal health. In: Konur O (ed) Handbook of Algal Science, Technology and Medicine. Academic Press, Elsevier

9. Stewart I, Seawright AA, Shaw GR (2008) Cyanobacterial poisoning in livestock, wild mammals and birds-an overview. In: Hudnell KH (ed) Cyanobacterial Harmful Algal Blooms: State of the Science and Research Needs. Springer, New York

10. Zhang F, Lee J, Liang S et al (2015) Cyanobacteria blooms and non-alcoholic liver disease: evidence from a county level ecological study in the United States. Environ Health 14:41

11. Hamilton DP, Wood SA, Dietrich DR, Puddick J (2014) Costs of harmful blooms of freshwater cyanobacteria. In: Sharma NK, Rai AK, Stal L (eds) Cyanobacteria: An Economic Perspective, Wiley, Hoboken.

12. Verburg P, Horrox J, Chaney E, Rutherford JC, Quinn JM, Wilock RJ, Howard-Williams CW (2013) Nutrient ratios, differential retention, and the effect on nutrient limitation in deep oligotrophic lake. Hydrobiologia 718:119-130

13. Paerl HW, Gardner WS, Havens KE, Joyner AR, McCarthy MJ, Newell SE, Qin B, Scott JT (2016) Mitigating cyanobacterial harmful algal blooms in aquatic ecosystems impacted by climate change and anthropogenic nutrients. Harmful Algae 54:213-222 
14. Choi H, Han C, Antoniou MG (2021) Sustainable and green decomposition of cyanotoxins and cyanobacteria through the development of new photocatalytic materials. Curr Opin Green Sustain Chem 28:100444

15. Matthijs H, Visser P, Reeze B, Meeuse J, Slot PC, Wijn G, Talens R, Huisman $J$ (2012) Selective suppression of harmful cyanobacteria in an entire lake with hydrogen peroxide. Water Res 46(5):1460-1472

16. Samuilov VD, Timofeev KN, Sinitsyn SV et al (2004) H2O2-Induced Inhibition of Photosynthetic $\mathrm{O}_{2}$ Evolution by Anabaena variabilis Cells. Biochemistry (Moscow) 69:926-933

17. Chakravarty D, Bihani SC, Banerjee M, Ballal A (2019) Novel molecular insights into the anti-oxidative stress response and structure-function of a salt-inducible cyanobacterial Mn-catalase. Plant Cell Environ 42:2508-2521

18. Piel T, Sandrini G, White E, Xu T, Schuurmans JM, Huisman J, Visser PM (2020) Suppressing cyanobacteria with hydrogen peroxide is more effective at high light intensities. Toxins 12:18

19. Sandrini G, Piel T, Xu T, White E, Qin H, Slot PC, Huisman J, Visser PM (2020) Sensitivity to hydrogen peroxide of the bloom-forming cyanobacterium Microcystis PCC 7806 depends on nutrient availability. Harmful Algae 99:101916

20. Matthijs CP H, Schuurmans M, Antoniou MG, Brient L, Edwards C, Gurbuz F, Jasser I, Koker L, Meriluoto J, Simeunovic J, Svircev Z, Stoica E, Vasas G, Vitonyte I, Luimstra V, Weenink, E, Visser P (2016) Mitigation of cyanobacteria with hydrogen peroxide-experiments with water from 11 European lakes. Poster Presentation 23-27 October, 2016 ICTC10 Meeting, Wuhan, China

21. Wang H, Tianyi Y, Li T, Zhen CZ, Yinan WY, Qin C (2016) Properties of calcium peroxide for release of hydrogen peroxide and oxygen: a kinetics study. Chem Eng J. 303:450-457

22. Rogers SO, Bendich AJ (1994) Extraction of total cellular DNA from plants, algae and fungi. Plant Molecular Biology Manual. Springer, Netherlands, pp 183-190

23. Chernova E, Russkikh I, Voyakina E, Zhakovskaya Z (2016) Occurrence of microcystins and anatoxin-a in eutrophic lakes of Saint Petersburg. Northwestern Russia Oceanol Hydrobiol Stud 45(4):466-484

24. Sellers RM (1990) Spectrophotometric Determination of Hydrogen Peroxide Using Potassium Titanium (IV) Oxalate. Analyst 105:950-954

25. Jakubowska N, Szeląg-Wasielewska E (2015) Toxic picoplanktonic cyanobacteria-review. Mar Drugs 13(3):1497-1518

26. Mazur-Marzec H, Sutryk K, Kobos J, Hebel A, Hohlfeld BA, Toruńska A, Kaczkowska MJ, Łysiak-Pastuszak E, Kraśniewski W et al (2013) Occurrence of cyanobacteria and cyanotoxins in the Southern Baltic Proper Filamentous cyanobacteria vs single-celled picocyanobacteria. Hydrobiologia 701:235-252

27. Ni Z, Shengrui Wang S, Jingjing Cai J, Hong Li H, Alan Jenkins A, Maberly SC, SC, May L, (2019) The potential role of sediment organic phosphorus in algal growth in a low nutrient lake. Environ Pollut 255(2):113235

28. EC, (2000) Directive 2000/60/EC of the European Parliament and of the Council establishing a framework for Community action in the field of water policy. OJ L 327:1-72

29. Guildford SJ, Hecky RE (2000) Total nitrogen, total phosphorus, and nutrient limitation in lakes and oceans: Is there a common relationship? Limnol Oceanogr 45(6):1213-1223
30. Symons CC, Arnott SE, Sweetman JN (2012) Nutrient limitation of phytoplankton communities in Subarctic lakes and ponds in Wapusk National Park. Canada Polar Biol 35:481-489

31. Levine M, Whalen S (2001) Nutrient limitation of phytoplankton production in Alaskan Arctic foothill lakes. Hydrobiologia 455:189-201

32. Chorus I, Spijkerman E (2020) What Colin Reynolds could tell us about nutrient limitation, N: P ratios and eutrophication control. Hydrobiologia. https://doi.org/10.1007/s10750-020-04377-w

33. Ngwa FF, Madramootoo CA, Jabaji S (2014) Comparison of cyanobacterial microcystin synthetase (mcy) E gene transcript levels, mcy E gene copies, and biomass as indicators of microcystin risk under laboratory and field conditions. MicrobiologyOpen 3(4):411-425

34. Wang X, Wang P, Wang C, Hu B, Ren L, Yang Y (2018) Microcystin biosynthesis in Microcystis aeruginosa: Indirect regulation by iron variation. Ecotoxicol Environ Saf 148:942-952

35. Salvador D, Churro C, Valério E (2016) Evaluating the influence of light intensity in mcyA gene expression and microcystin production in toxic strains of Planktothrix agardhii and Microcystis aeruginosa. J Microbiol Methods 123:4-12

36. Zuo J, Chen L, Shan Ket al (2018) Assessment of different mcy genes for detecting the toxic to non-toxic Microcystis ratio in the field by multiplex qPCR. J Ocean Limnol 36:1132-1144

37. Beversdorf LJ, Chaston SD, Miller TR, McMahon KD (2015) Microcystin mcyA and mcyE Gene Abundances Are Not Appropriate Indicators of Microcystin Concentrations in Lakes. PLoS ONE 10(5):e0125353

38. Pacheco ABF, Guedes IA, Azevedo SM (2016) Is qPCR a Reliable Indicator of Cyanotoxin Risk in Freshwater? Toxins 8:172

39. Lu S, Zhang X, Xue Y (2017) Application of calcium peroxide in water and soil treatment: a review. J Hazard Mater 337:163-177

40. Isles PDF (2020) The misuse of ratios in ecological stoichiometry. Ecology 101(11):e03153. https://doi.org/10.1002/ecy.3153

41. Ballot A, Fastner J, Wiedner C (2010) Paralytic Shellfish Poisoning ToxinProducing Cyanobacterium Aphanizomenon gracile in Northeast Germany. Appl Environ Microbiol 76(4):1173-1180

42. Rantala-Ylinen A, Känä S, Wang H, Rouhiainen L, Wahlsten M, Rizzi E, Berg K, Gugger M, Sivonen K (2011) Anatoxin-a Synthetase Gene Cluster of the Cyanobacterium Anabaena sp. Strain 37 and Molecular Methods To Detect Potential Producers. Appl Environ Microbiol 77(20):7271-7278

\section{Publisher's Note}

Springer Nature remains neutral with regard to jurisdictional claims in published maps and institutional affiliations.

\section{Submit your manuscript to a SpringerOpen ${ }^{\circ}$ journal and benefit from:}

- Convenient online submission

- Rigorous peer review

- Open access: articles freely available online

- High visibility within the field

Retaining the copyright to your article

Submit your next manuscript at springeropen.com 